\title{
"NIENASYCENI ADRENALINĄ"
}

ASPEKT ETYCZNY SPORTÓW EKSTREMALNYCH

„Ceną rzeczy jest ilość tego, co nazwałbym życiem, które należy za nią wymienić natychmiast albo w ostatecznym rozrachunku".

Henry David Thoreau, Walden (tłum. Halina Cieplińska) ${ }^{1}$

13 lipca 1990 roku na Piku Lenina w Pamirze doszło do największej zbiorowej tragedii w historii światowego himalaizmu. Pod lawiną zginęło 43 alpinistów. Kolejne lata przyniosły ze sobą tragedie, w wyniku których góry zabrały kilkudziesięciu alpinistów różnych narodowości. 5 sierpnia 2004 roku 11 alpinistów poniosło śmierć, rzucając wyzwanie Chan Tenri w Tienszanie, rok później 20 października 18 alpinistów straciło życie na Kang Guru w Himalajach (dane przytoczone w książce Janusza Kurczaba pt. Polskie Himalaje) ${ }^{2}$. Do smutnej listy śmiałków rzucających wyzwanie najwyższym z gór dołączyć należy zasłużonych polskich himalaistów, którzy w mijającym roku odeszli realizując swe marzenia.

Od kilkudziesięciu już lat media obfitują w doniesienia o ekstremalnych wyprawach, nowych osiągnięciach i nowatorskich wyczynach sportowców. W marcu 2012 roku byliśmy świadkami sukcesu polskiej ekipy himalaistów, która jako pierwsza w historii dokonała zimowego wejścia na Gaszerbrum I w Karakorum. Przez kilka dni radość obser-

${ }^{1}$ Cyt. za: B. Mc Donald, Ucieczka na szczyt, tłum. W. Fusek, R. Palacz, Warszawa 2012, s. 105.

${ }^{2}$ J. Kurczab, Największe tragedie, [w:] Polskie Himalaje, cz. 5, Warszawa 2008, s. 13. 
watorów zmącona była jednak niepokojącymi doniesieniami o odmrożeniach u dwóch himalaistów oraz złym stanie pogody zagrażającej ich bezpieczeństwu. Ostatecznie Adam Bielecki i Janusz Gołąb zdołali dotrzeć do bazy, realizując tym samym historyczne wyzwanie.

Niestety zaraz potem euforię marcowego przedsięwzięcia przyćmiła informacja o zaginięciu trójki członków analogicznej wyprawy kierowanej przez Gerfrieda Göschla. W przeciwieństwie do wcześniejszych medialnych doniesień dotyczących dramatycznej sytuacji dwójki polskich zdobywców, informacja o tragedii ekipy Göschla okazała się prawdziwa.

W medialnym zamęcie dało się jednak wyczuć pewien niesmak spowodowany - zdaniem polskich himalaistów - brakiem rzetelności w przekazie. Polska ekipa wydała oświadczenie krytykujące Telewizję Polską za „nakręcanie sensacji i bezrefleksyjne manipulowanie faktami” ${ }^{3}$. Odnosząc się do informacji o rzekomych trudnościach towarzyszących Polakom przy zejściu, zwrócono uwagę na brak odpowiedzialności i etyki dziennikarskiej. Sportowcy napisali: „Chcielibyśmy zaapelować do dziennikarzy, że nie jesteśmy materiałem, tylko żywymi ludźmi, którzy mają rodziny i przyjaciół. Rozsiewanie tego typu sensacyjnych, nieprawdziwych informacji jest niezwykle szkodliwe, zwłaszcza w przypadku tego sportu, który sam w sobie niesie duże ryzyko, straszenie rodzin i opinii publicznej niczemu nie służy. Jesteśmy oburzeni, naszym zdaniem sprawą powinna się zająć Komisja Etyki Mediów" . Pod oświadczeniem podpisali się: Artur Hajzer, Janusz Gołąb, Adam Bielecki i Agnieszka Bielecka.

Powyższa sytuacja ujawnia ogrom wątpliwości, jakie mogą się pojawiać na marginesie wielkiego wydarzenia, i skłania do refleksji etycznej, nieuchronnie towarzyszącej podobnym wyzwaniom.

Pojawia się coraz częściej stawiane pytanie o granice. Dwójka wspinaczy podjęła trud zmierzenia się z wyzwaniem niezwykłym: uznana za jedną z najbardziej niebezpiecznych gór Himalajów została zdobyta w zimie, w dodatku bez użycia aparatury tlenowej. Nikogo nie trze-

3 Strona Polskiego Himalaizmu Zimowego, http://off,sport.pl/off/1,111379,11347491, Polscy_himalaisci_apeluja_do_mediow, html (11.12.2012).

4 Tamże (11.12.2012). 
ba przekonywać, jak wielkie ryzyko jest wpisane w podobne działanie. Niedługo potem polski himalaizm najdobitniej miał doświadczyć bezwzględności gór podczas tragicznej wyprawy na Broad Peak w 2013 roku, pozostawiając w zbiorowej świadomości traumę śmierci dwóch wspinaczy: Macieja Berbeki i Tomasza Kowalskiego.

W tym kontekście wydaje się zasadne postawienie pytania o konsekwencje i odpowiedzialność śmiałków ryzykujących życie na szczytach świata.

1. DUCH NASZYCH CZASÓW:

BŁOGOSŁAWIEŃSTWO CZY PRZEKLEŃSTWO?

Podejmując analizę problematyki ryzyka wspinaczy, nie sposób uciec od szeregu zagadnień występujących w całym obszarze szeroko rozumianych sportów ekstremalnych. W obecnych czasach tradycyjny model sportu zostaje zakwestionowany, aktywność fizyczna zmienia swój charakter, tym samym modyfikuje się również cele i zadania z nią związane. Wzrastające tempo życia, dążenie do szybszego i efektowniejszego osiągania celów, pogoń za sukcesem stają się zjawiskami dominującymi. Swoistej zachłanności przejawiającej się w życiu na coraz większym gazie, wciąż szybszym, dłuższym i lepszym, towarzyszy permanentne poczucie niezaspokojenia, niedosytu. W sferze emocjonalnej rodzi się głód wrażeń coraz bardziej nietypowych i intensywnych.

Psychologowie wskazują na współczesne tendencje do tzw. życia na maksa. Praca ponad siły, coraz większy przepływ informacji, poszukiwanie coraz oryginalniejszych rozrywek ujawnia dążenie do życia „bardziej”, „więcej”, „mocniej”. Doskonałym przykładem może być hasło w jednej z ostatnich reklam telefonii komórkowej, streszczające się w jednym słowie - „bardziej”. Nie jest konieczne wyjaśnianie, o co chodzi w przekazie, dla współczesnego odbiorcy wszystko jest jasne i zrozumiałe.

Życiu na maksa towarzyszy podwyższony poziom stresu lub pobudzenia. Adrenalina wydzielająca się w stresowych sytuacjach powodu- 
je szereg reakcji fizjologicznych, przygotowujących organizm do walki ${ }^{5}$. Z jej pomocą odczucie specyficznego „haju” staje się udziałem sportowca ekstremalnego. Wrażenia te są tak bardzo pożądane, że zaczynają być traktowane jako niezbędne. W konsekwencji poszukiwacz przeżyć sięga po coraz więcej. Szybko powstaje efekt błędnego koła, gdyż organizm, próbując sobie radzić ze zwiększoną dawką adrenaliny, po prostu się na nią uodparnia. Mechanizmy obronne zostają poważnie zniekształcone lub stępione, stwarzając realne zagrożenie dla posiadającego ograniczenia ludzkiego organizmu.

W skrajnych przypadkach adrenalina staje się motorem i sensem działania. Aktywność stymulowana niekontrolowaną dawką adrenaliny niejednokrotnie dotyka dziedziny sportu, zmieniając nieco jego charakter, przyczynia się do tworzenia zupełnie nowych dyscyplin. Choć zrównywanie sportów całkiem nowych z pełnym etosu i bogatej historii himalaizmem czy alpinizmem nie wydaje się w pełni uzasadnione, są jednak przesłanki wskazujące niebezpieczne tendencje pojawiające się również we wspinaczce. Mówi się o przewartościowaniu zachodzącym w mentalności „ludzi gór”. Alpinista Janusz Zdebski i psychiatra Zdzisław Ryn diagnozują tę zmianę pisząc, że „dokonała się [...] podstawowa zmiana w systemie wartości. Miejsce gór jako sanktuarium alpinisty zajęła czynność wspinania. [...] Skoro więc naczelną wartością dla współczesnego alpinisty jest czynność wspinania, to góry są instrumentem realizacji tych zamierzeń. Dokonała się więc instrumentalizacja gór, które dla alpinistów przełomu XIX i XX wieku były wartością autoteliczną"6.

Jakie są powody zmiany podejścia do aktywności fizycznej realizowanej przez sport?

Jedną z przyczyn jest niewątpliwie wszechobecna postawa konsumpcyjna, a co za tym idzie, komercjalizacja niemal wszystkich dziedzin życia. Sport nie jest tu wyjątkiem. Znawca tematu, a zarazem wielki kry-

${ }^{5}$ Por. P. Chocholska, Sporty ekstremalne i uzależnienie od adrenaliny, http://psycho tekst.com/artykuły.php?nr=118 (11.12.2012).

${ }^{6}$ J. Zdebski, J. Z. Ryn, Alpinizm i etyka, [w:] „Studia Humanistyczne AWF w Krakowie" (2001) nr 1, s. 86-87. 
tyk sportów ekstremalnych Andrzej Pawłucki wskazuje, że ryzykowne poczynania wzbudzane są w sposób sztuczny mechanizmami wolnorynkowymi. Pisze: „Niby jak można pojąć obecne pokolenie «adrenalinowców», które głośno krzyczy, że właśnie adrenaliny mu potrzeba. Tak chyba jedynie, że ktoś musiał mu wmówić, że tego mu potrzeba, a następnie wytworzyć głód owej potrzeby, aby głodny już sam zaczął upominać się o to, czego chcieć musi, głodny adrenaliny będzie siebie karmił, a w spełnieniu tej potrzeby pomoże mu ten, który za produkcję i konsumpcję każe sobie zapłacić"

Potwierdzeniem powyższych uwag mogą być liczne przykłady nowych dyscyplin sportowych wymagających znacznych nakładów finansowych. Jednocześnie są one sposobem ucieczki od monotonii życia korporacyjnego i problemów świata biznesu. Oferowane sposoby rozładowywania stresu przybierają coraz bardziej wyrafinowaną formę. Sporty potencjalnie nieniosące ze sobą ryzyka przeobrażają się w dyscypliny mrożące krew w żyłach. Dobrym przykładem może być jazda na rowerze, której ekstremalna odmiana pod nazwą downhill (zjazd po stromym zboczu) czy narciarstwo offroadowe (poza nartostradą) zyskują coraz większą popularność. Z kolei sporty jeszcze nie tak dawno uznawane za ekstremalne (według Encyklopedii sportów ekstremalnych), takie jak np. nurkowanie, snowboarding czy wspinaczka wysokogórska wciąż ewoluują w kierunkach nie do końca przewidywalnych. Tworzą kolejne mutacje wychodzące naprzeciw oczekiwaniom żądnych wrażeń miłośników wspomnianych form aktywności. Dobrym przykładem jest nurkowanie, które samo w sobie niesie pewną dozę ryzyka, zaś „wzbogacone” przez czynniki pogodowe przeobraża się w nurkowanie podlodowe. Przy nartostradach powstają specjalne „parki” dla snowboardzistów-akrobatów. Coraz większe grono amatorów zyskuje wspinaczka bez asekuracji bądź aparatury tlenowej. Niemal w każdej dziedzinie bite są rekordy.

${ }^{7}$ Cyt. za: A. Pawłucki, Turysta ekstremalny. Między indoktrynowanym ryzykiem a bezpiecznym sensem, [w:] Edukacja poprzez sport, red. Z. Dziubiński, Warszawa 2004, s. 317; T. Sahaj, „Homo transgressivus”, czyli o sportach ekstremalnych, [w:] „Sport Wyczynowy" (2005) nr 11-12 (491-492), s. 65-73. 


\section{EKSTREMALNY, CZYLI JAKI?}

Dynamika powstawania nowych form aktywności o charakterze ekstremalnym jest tak wielka, że tworzenie wykazów czy tabeli sportów uznawanych za ryzykowne w wyniku ciągłej dezaktualizacji staje się bezcelowe. Podejmując jednak próbę jakiegokolwiek ich usystematyzowania czy charakterystyki, możemy wskazać kilka cech wspólnych, łączących większość sportów określanych mianem ekstremalnych.

Pierwszą cechą wspólną widoczną przy tego typu aktywności jest wysokie ryzyko, a przez to pewnego rodzaju elitarność. Atrakcyjność oferowanych form spędzania wolnego czasu polega na wyrafinowanym konstruowaniu coraz bardziej nietypowych i oryginalnych wyzwań stawianych zainteresowanym. Chęć doznawania nowych, elitarnych wrażeń, a w konsekwencji ich przeżywanie wywołuje tzw. „efekt endorfinowy", o którym pisze Tomasz Sahaj ${ }^{8}$. Efekt ten uzyskiwany jest poprzez dostarczenie mózgowi znacznej ilości substancji o charakterze narkotyzującym, takich jak adrenalina, wywołujących produkcję endorfiny, czyli hormonu szczęścia. Adrenalina związana z ryzykiem potęguje wspomniany efekt.

Wzmożona potrzeba przeżywania doświadczeń w sposób „skondensowany" prowadzi do swoistego uzależnienia od mocnych wrażeń. Alpinista-psychiatra Zdzisław Ryn tak opisuje stan umysłu towarzyszący ekstremalnym przeżyciom: „Głównym motorem pchającym do samotnej wspinaczki jest [...] przemożna potrzeba ryzyka i niebezpieczeństwa, granicząca z samounicestwieniem. Tylko w skrajnie niebezpiecznej sytuacji na granicy życia i śmierci alpiniści przeżywają stany emocjonalnego pobudzenia o cechach ekstazy"

Alfred Alvarez, cytowany przez Jona Krakauera w książce pt. Wszystko za Everest, podobnie tłumaczy opisywany mechanizm, wskazując jed-

8 T. Sahaj, „Homo transgressivus”..., dz. cyt., s. 67.

9 Cyt za: T. Sahaj, Z. Ryn, Z doznań psychicznych wspinaczy samotnych, [w:] Materiaty z teorii i dydaktyki sportów wspinaczkowych, red. A. Matuszyk, Kraków 1993, s. 67. 
nocześnie na jego nieodwracalne konsekwencje. Pisze: „Być może takie jest racjonalne uzasadnienie wszelkich sportów ekstremalnych: celowo podwyższasz stawkę, zmuszając się do większego wysiłku i koncentracji, by niejako oczyścić umysł z rzeczy nieistotnych. To model prawdziwego życia w małej skali - z jedną różnicą: w przeciwieństwie do normalnej życiowej rutyny, kiedy to błędy daje się zazwyczaj poprawić, a rozmaite rodzaje niedociągnięć jakoś pokryć, tutaj twoje działania, choćby nawet trwały bardzo krótko, są kwestią życia lub śmierci"10.

Kolejną cechą charakterystyczną dla sportów ekstremalnych, deklarowaną przez samych użytkowników, jest swoiście rozumiana chęć pokonywania własnych słabości. Dlatego, jak pisze Tomasz Sahaj, „uczestnictwo w sportach ekstremalnych wiąże się z pokonywaniem skrajnych trudności zewnętrznych, ograniczeń psychicznych i związanych z tym silnych emocji"11.

Trudno byłoby poddawać krytyce ideę zasadniczo słuszną. Każdy człowiek jest zobowiązany do ciągłej pracy nad sobą, do doskonalenia siebie, przełamywania barier ograniczających jego rozwój. Determinacja w tym względzie zasługuje na uznanie. W przypadku wyzwań ekstremalnych jednak pojawia się problem z określeniem granic w „pokonywaniu samego siebie”. Zasadne wydaje się pytanie o słuszność absolutyzowania i realizacji jednej wartości kosztem innych. Pokonywanie własnych słabości nie może iść w parze z niewspółmiernym ryzykiem, wartość życia nie może być stawiana na równi z chęcią eliminowania osobistych ograniczeń.

Koncentracja na samym sobie powoduje w końcu specyficzne „wycofanie się", zamknięcie na innych. Stanowi to zaprzeczenie jednej z podstawowych idei tworzących etos sportowca otwartego na wspólne, zespołowe przeżywanie aktywności ruchowej, zdrową rywalizację i walkę fair play. Jak pisze ks. Maciej Ostrowski, analizujący współczesne sposoby wykorzystywania wolnego czasu, sport, który ze swej istoty ma pro-

${ }^{10}$ A. Alvarez, The Savage God: a Study of Suicie, London 1990, cyt. za: J. Krakauer, Wszystko za Everest, tłum. D. Konowrocka, Warszawa 2009, s. 88.

11 T. Sahaj, „Homo transgressivus”..., dz. cyt., s. 65. 
wadzić do rozwoju międzyosobowych kontaktów, przestaje pełnić swoją rolę. Wypoczynek nie otwiera człowieka na bliźnich i przestaje być wspólnototwórczy. Jak pisze Ostrowski, „Jego cel zostaje jednostronnie ograniczony, stając się bardziej samozaspokojeniem"12. Uczestnik sportów ekstremalnych nie potrzebuje partnerów, z którymi się mierzy, on rywalizuje z samym sobą.

Znacznie dalej w swojej krytyce motywów towarzyszących wspinaczce ekstremalnej posuwa się David Roberts, cytowany przez autora słynnej książki Wszystko za Everest. Roberts stawia pytanie: „W jakim stopniu urok wspinaczki polega na uproszczeniu relacji międzyludzkich, redukcji przyjaźni do bezkonfliktowego współdziałania (jak na wojnie), zastąpienia czymś Innym (górą, wyzwaniem) związku z drugim człowiekiem? Za mistyczną otoczką pełnej przygód swobodnej włóczęgi prawdziwych twardzieli - tą niezbędną odtrutką na nieuniknione w naszej kulturze wygody i udogodnienia - może kryć się rodzaj niedojrzałej odmowy poważnego potraktowania problemów starzenia się, kruchości bliźnich, zobowiązań w związkach międzyludzkich, słabości wszelkiego rodzaju, powolnych i mało widowiskowych kolei losu"13. Inaczej mówiąc - brak akceptacji życia takiego, jakie jest.

Sahaj przywołuje cytowanego przez Zbigniewa Dziubińskiego Andrzeja Pałuckiego, który w sporcie ekstremalnym widzi zagrożenie dla humanistycznej wartości sportu. Pisze, że Pawłucki „na przykładzie turysty ekstremalnego ukazał mechanizmy pchające człowieka w cywilizację śmierci, kulturę hedonizmu, w postmodernistyczny chaos"14. Konsekwencje wynikające z zakwestionowania tradycyjnych wartości obecnych w sporcie moga prowadzić do zagubienia.

${ }^{12}$ M. Ostrowski, Duszpasterstwo wobec problemu wolnego czasu człowieka. Aspekt moralno-pastoralny ze szczególnym uwzględnieniem zagadnień turystyki, Kraków 1996, S. 172 .

${ }^{13}$ Cyt. za: J. Krakauer, D. Roberts „Patej Agonistes”, Chwile zwątpienia, [w:] J. Krakauer, Wszystko za Everest, tłum. D. Konowrocka, Warszawa 2009, s. 154.

${ }^{14}$ Cyt. za: T. Sahaj, Z. Dziubiński, O edukacji poprzez sport z różnych pozycji teoretycznych $i$ metodologicznych, [w:] "Sport Wyczynowy” (2004) nr 11-12, s. 68. 


\section{PROBLEM ODPOWIEDZIALNOŚCI}

Zasklepianie się i koncentracja na samym sobie, prowadząca do egocentryzmu, w szczególny sposób ujawniają się w odniesieniu do relacji z otoczeniem, czyli bliskimi. Nikt nie jest tylko „samotną wyspą na oceanie świata”, każdy pozostaje w dalszym lub bliższym związku z ludźmi dookoła.

W tym kontekście warto zadać pytanie, czy mamy moralne prawo skazywać bliskich na cierpienie spowodowane permanentnym strachem o nasze życie. Wątpliwości te rodzą się ze szczególną mocą zwłaszcza w sytuacji, w której decyzja o uczestnictwie w ryzykownych poczynaniach idzie w parze z decyzją o założeniu rodziny. W tym przypadku wydaje się, że obydwie pożądane wartości nie mogą być realizowane jednocześnie: jedna z nich determinuje bądź wyklucza drugą. Z konieczności dokonania wyboru pomiędzy nimi musi zdawać sobie sprawę każdy, kto choćby w stopniu elementarnym posiada poczucie odpowiedzialności.

I właśnie do kwestii odpowiedzialności sprowadza się większość dyskusji o zagrożeniach związanych z nowymi dyscyplinami sportowymi. Dyskusje dotyczą zaopatrzenia w odpowiedni sprzęt, niwelujący ewentualne wypadki, wyposażenia w specjalistyczną wiedzę niezbędną do uprawiania danej dyscypliny czy tworzenia etycznych kodeksów, mających regulować wzajemne relacje między sportowcami oraz ich stosunek do otaczającej przyrody.

Jednakże nie sposób uciec od problemu odpowiedzialności rozumianej nieco szerzej, odpowiedzialności przez duże „O”. To z nią mają do czynienia sportowcy pozostający w związkach małżeńskich bądź mający dzieci. Odpowiedzialność nie jest już tylko sprawą jednej osoby, rozciąga się o wiele szerzej, na pozostałych członków rodziny, za których bierze się odpowiedzialność w chwili nawiązania relacji rodzinnych.

Wspomniany problem niewątpliwie istnieje. Jednak brak zbiorowej refleksji na ten temat może dziwić. To oczywiste, że uwaga opinii publicznej w pierwszej kolejności koncentruje się na samym wydarzeniu, jakim jest dany wyczyn, oraz jego autorach. Jednak należy zdać sobie sprawę z faktu, że „wielokrotnie za bezprecedensowe sukce- 
sy w górach polskie wyprawy płaciły cenę najwyższą"15. We wstępie do tomu pt. Największe tragedie, opisującym najtragiczniejsze katastrofy w Himalajach, Wojciech Fusek dotyka najtrudniejszego aspektu himalaizmu - śmierci w górach. „Śmierci, która - jak pisze Fusek - często odziera wspinaczkę z romantyzmu"16. Śmierci, która nie jest tylko dla wspinacza końcem osobistej przygody zwanej życiem, lecz rodzi także poważne konsekwencje dla jego bliskich.

Sytuacja życiowych partnerów osób uprawiających sporty ekstremalne jest szczególnie trudna. Ich codzienność nacechowana jest ciągłym lękiem o życie i zdrowie partnera. Stosunkowo łatwo pogodzić się z faktem nieustannego ryzyka w momencie, gdy oboje dzielą wspólną pasję i w pełni świadomie decydują się ponosić jej ewentualne konsekwencje. Jednak to rzadkie przypadki, znacznie częściej to jedna ze stron zmaga się z permanentną obawą o bezpieczeństwo bliskiej jej osoby. Jednocześnie ma ona świadomość potrzeb partnera-ryzykanta, zdaje sobie sprawę z pewnego rodzaju „uwikłania” w nieuleczalną pasję, która często wypełnia sporą część jego życia i stanowi o jego szczęściu.

Cennym świadectwem owych dylematów są refleksje himalaistów zmuszonych do rezygnacji z wyzwania w obliczu nieuchronnego ryzyka. W artykule zatytułowanym Egoizm, traktującym o wewnętrznych zmaganiach z własnymi pragnieniami, Łukasz Długowski analizuje sytuację, w której bliski realizacji marzenia o zdobyciu kolejnego szczytu, uświadamia sobie realność zagrożenia lawinowego. Pisze: „Myśl, że jest zbyt ryzykownie, kiełkuje mi w głowie od jakiegoś czasu. Teraz nasila się coraz bardziej. [...] Po jednej stronie marzenie, które przez naście lat chciałem zrealizować. [...] Byłem w bajce, o której śniłem od zawsze. I teraz mam z tego zrezygnować? Ale po drugiej stronie jest mój synek i moja dziewczyna, do której muszę wrócić w jednym kawałku. Suma wszystkich strachów - o to, że do nich nie wrócę, że uduszę się pod lawiną, że przez 15 minut życia, które pozostanie mi pod śniegiem, będę pluł sobie w brodę: mogłem odpuścić i wrócić w kolejnym roku...

\footnotetext{
${ }^{15}$ W. Fusek, [w:] J. Kurczab, Polskie Himalaje, dz. cyt., s. 8.

16 Tamże.
} 
Prawdopodobnie po raz pierwszy w życiu podejmuję w pełni nieegoistyczną decyzję. Postanawiam, że moje pragnienia nie są na tyle istotne, żeby ryzykować utratę Jej i Jego" ${ }^{\prime 17}$.

Jak trudna jest opisana sytuacja, świadczą dalsze słowa autora, który próbuje wytłumaczyć swoją decyzję przed samym sobą. Gdzieś na końcu owych rozważań dochodzi do ważkich i świadczących o ogromnej dojrzałości wniosków. Wyznaje: „Obiecałem sobie, że kiedy wrócę, będę opowiadał o mojej «porażce». O tym, jak wiele mnie to nauczyło. O tym, co jest naprawdę ważne w moim życiu - żadna góra nie jest warta nawet paznokcia"18.

Świadectwem, że refleksja lub wątpliwość nie jest obca wspinaczom, są liczne przemyślenia czynione w trakcie wędrówek. Jon Krakauer przytacza wspomnienia wspinającego się na Mount Everest Tomasa Hornbeina. Morderczy wysiłek, jaki alpinista włożył w pokonanie wszystkich trudności skłaniały do podważenia sensowności wyprawy. Zwątpieniu daje wyraz w gorzkiej konkluzji: „Czasem [...] zastanawiałem się, czy nie przeszedłem całej tej długiej drogi tylko po to, by zrozumieć, że szukam czegoś, co zostawiłem za sobą" ${ }^{\prime 19}$.

W podobnym tonie wypowiada się Jon Krakauer w słynnej książce Wszystko za Everest, traktującej o cenie, jaką się płaci za realizację zbyt śmiałych życiowych marzeń. Śniący od dzieciństwa o zdobyciu Mount Everestu Krakauer pisze: „Próba zdobycia tego szczytu jest jednak z samej swej natury działaniem nieracjonalnym - zwycięstwem pożądania nad rozumem" ${ }^{20}$. Ta gorzka konkluzja w szczególny sposób wybrzmiewa na tle dramatu, który rozegrał się w 1996 roku na Evereście i którego naocznym świadkiem stał się Krakauer. Pod szczytem zginęło wówczas dziewięciu wspinaczy, wśród których znajdowało się czterech towarzyszy z ekipy Krakauera. W obliczu tak traumatycznych przeżyć pytanie

17 Ł. Długowski, Egoizm, [w:] „Gorce. Magazyn Turystyki Górskiej” (2012) nr 8, s. 40. 18 Tamże.

${ }^{19}$ Cyt. za J. Krakauer, T. F. Hornbein, Everest: grań zachodnia, [w:] J. Krakauer, Wszystko za Everest, dz. cyt., s. 56.

${ }^{20}$ J. Krakauer, Wszystko za Everest, dz. cyt., s. 12. 
o zasadność organizowania tzw. wypraw komercyjnych dla amatorów mocnych wrażeń prędzej czy póżniej musi się pojawić.

Niestety bywa jednak i tak, że towarzysz życia pasjonata sportu ekstremalnego poddany zostaje swoistemu szantażowi emocjonalnemu. W obliczu argumentów o samorealizacji partnera trywialne lęki o jego życie wydają się tylko histeryczną fanaberią. Zapewnienie zaś bliskiej osobie spokoju kosztem realizacji pasji rodzi frustrację i żal do partnera. Trudno więc oczekiwać, że bliski pasjonata rozpocznie batalię, tak czy owak mając świadomość nieuchronności porażki. W tej sytuacji odpowiedzialność spoczywa na tym, który próbuje godzić ze sobą wartości trudne do pogodzenia: z jednej strony niebezpieczną pasję, z drugiej życie rodzinne. Brak decyzji rozstrzygającej o wyborze jednej z nich może świadczyć o zachłanności. Chęć osiągania sukcesów i posiadania rodziny nawet za cenę ryzyka okazuje się zbyt silna. Owa zachłanność nieuchronnie prowadzi do dramatu dowodzącego, że wdzierająca się w niemal każdą dziedzinę życia chciwość niejedno ma imię.

Jednym z najbardziej przejmujących fragmentów książki Kurczaba dotyczącej tragedii w Himalajach jest świadectwo matki Wandy Rutkiewicz, która po blisko dwudziestu latach od zniknięcia córki wciąż wierzy w jej powrót. Cytowane są też słowa Wandy, wypowiedziane przez nią w bazie pod Kangchendzongą, z której nie dane jej było powrócić: „Dla mnie umrzeć tam na górze nie byłoby niczym niezwykłym. To byłoby całkiem proste. Ostatecznie większość moich przyjaciół czeka na mnie tam, wysoko" ${ }^{21}$.

Dla matki Wandy Rutkiewicz jej śmierć nie była czymś prostym. Jest ona przykładem dramatu, będącego udziałem tych wszystkich, którzy duchowo pozostają z bohaterami coraz bardziej spektakularnych osiągnięć. Pamięć o niemym towarzyszu ryzykownych przedsięwzięć niech będzie tym, co w refleksji o wielkich sukcesach znajdzie w końcu należne jej miejsce.

${ }^{21}$ http://wandarutkiewicz.inmemoriam.org/ (26.10.2015). 


\section{INSATIABLE DEMAND FOR ADRENALINE}

ETHICAL ASPECT OF EXTREME SPORTS

SUMMARY

In our modern times in all walks of life the possibilities for expanding human activities is a widely discussed issue. It is especially valid in extreme sports where the line between the death and life is very thin. The price paid by such extreme performers poses a question about the ethical aspect of their spectacular performances and their motivation behind them. Thus the question about the responsibility for their own lives and particularly about the lives of the others is put forward.

KEYWORDS

ethics, extreme sport, motivations, responsibility 